\title{
New perspectives in the diagnosis of pediatric male hypogonadism: the importance of AMH as a Sertoli cell marker
}

\author{
Novas perspectivas no diagnóstico do hipogonadismo pediátrico \\ masculino: a importância do AMH como marcador de células de Sertoli
}

Romina P. Grinspon', Rodolfo A. Rey ${ }^{1,2}$

1 Centro de Investigaciones Endocrinológicas (CEDIE, CONICET), Hospital de Niños Ricardo Gutiérrez, Buenos Aires, Argentina ${ }^{2}$ Department of Histology, Cell Biology, Embryology and Genetics, School of Medicine, University of Buenos Aires, Argentina
Correspondence to:

Romina P. Grinspon

Centro de Investigaciones

Endocrinológicas,

Hospital de Niños Ricardo Gutiérrez, Gallo 1330, C1425EFD

Buenos Aires, Argentina rgrinspon@cedie.org.ar

Received on 9/Oct/2011 Accepted on 16/Oct/2011

\section{SUMMARY}

Sertoli cells are the most active cell population in the testis during infancy and childhood. In these periods of life, hypogonadism can only be evidenced without stimulation tests, if Sertoli cell function is assessed. AMH is a useful marker of prepubertal Sertoli cell activity and number. Serum AMH is high from fetal life until mid-puberty. Testicular AMH production increases in response to FSH and is potently inhibited by androgens. Serum AMH is undetectable in anorchidic patients. In primary or central hypogonadism affecting the whole gonad and established in fetal life or childhood, serum AMH is low. Conversely, when hypogonadism affects only Leydig cells (e.g. LH $\beta$ mutations, LH/CG receptor or steroidogenic enzyme defects), serum AMH is normal or high. In pubertal males with central hypogonadism, AMH is low forTanner stage (reflecting lack of FSH stimulus), but high for the age (indicating lack of testosterone inhibitory effect). Treatment with FSH provokes an increase in serum AMH, whereas hCG administration increases testosterone levels, which downregulate AMH. In conclusion, assessment of serum AMH is helpful to evaluate gonadal function, without the need for stimulation tests, and guides etiological diagnosis of pediatric male hypogonadism. Furthermore, serum AMH is an excellent marker of FSH and androgen action on the testis. Arq Bras Endocrinol Metab. 2011;55(8):512-9

\section{Keywords}

Hypogonadotrophic hypogonadism; hypergonadotrophic hypogonadism; testis; anorchia; cryptorchidism; disorders of sex development

\section{SUMÁRIO}

As células de Sertoli são a população de células mais ativa nos testículos durante a primeira e segunda infância. Neste período, o hipogonadismo só pode ser evidenciado sem o uso de testes estimulatórios se a função das células de Sertoli for avaliada. O AMH é um marcador útil do número e da atividade das células de Sertoli no período pré-puberal. A concentração sérica de AMH é alta da metade da vida fetal até a metade da puberdade. A produção de AMH pelos testículos aumenta em resposta ao FSH e é potencialmente inibida por androgênios. $\mathrm{O}$ AMH sérico não é detectável em pacientes anorquídicos. No hipogonadismo central ou primário afetando a gônada inteira, ou estabelecido na vida fetal ou infância, a concentração de AMH sérica é baixa. Por outro lado, quando o hipogonadismo afeta apenas as células de Leydig (por exemplo, nas mutações, LH $\beta$, defeitos do receptor de LH/CG ou das enzimas esteroidogênicas), a concentração de AMH sérico é normal ou alta. Em meninos púberes com hipogonadismo central, a concentração de AMH é baixa para o estágio na escala deTanner (refletindo a falta de estímulo pelo FSH), mas alta para a idade (indicando a falta do efeito inibidor da testosterona). 0 tratamento com FSH provoca um aumento do AMH sérico, enquanto a administração de hCG aumenta os níveis de testosterona, que fazem a downregulation do AMH. Em conclusão, a concentração sérica de $\mathrm{AMH}$ é útil na avaliação da função gonadal, excluindo a necessidade de testes estimulatórios, e direciona o diagnóstico etiológico do hipogonadismo pediátrico masculino. Além disso, o AMH sérico é um marcador excelente da ação do FSH e dos androgênios nos testículos. Arq Bras Endocrinol Metab. 2011;55(8):512-9

\section{Descritores}

Hipogonadismo hipogonadotrófico; hipergonadismo hipogonadotrófico; testículos; anorquia; criptorquidismo; desordens do desenvolvimento sexual 


\section{INTRODUCTION}

$\mathrm{T}$ The hypothalamic-pituitary-testicular axis undergoes maturational changes that are specific to each of its components along fetal and postnatal life. The axis has classically been described to have a master regulator, the hypothalamic gonadotropin-releasing hormone $(\mathrm{GnRH})$, driving pituitary gonadotropin ( $\mathrm{LH}$ and FSH) secretion, which finally regulates testicular function. Two discrete, though interacting, compartments are present in the testes from its initial differentiation in early fetal life through adulthood: the seminiferous tubules, containing Sertoli and germ cells, and the interstitial tissue, containing Leydig cells. Sertoli cells are known to have FSH receptors, whereas Leydig cells have LH receptors. Assessment of gonadal function has typically been focused on Leydig cell androgen secretion. In this review, we will address the relevance of anti-Müllerian hormone $(\mathrm{AMH})$ as a Sertoli cell marker in the understanding of prepubertal male hypogonadism.

\section{ONTOGENY OF THE HYPOTHALAMIC-PITUITARY- TESTICULAR AXIS}

Testes differentiate by the end of the $5^{\text {th }}$ embryonic week. Sertoli and germ cells form the seminiferous cords. Sertoli cells secrete AMH, responsible for the regression of Müllerian ducts, the anlagen of the uterus and Fallopian tubes. The onset of AMH secretion is independent of pituitary function. Afterwards, fetal FSH regulates Sertoli cell activity (1). Leydig cells located in the interstitial tissue secrete testosterone and insulinlike factor 3 (INSL3) in response to placental chorionic gonadotropin (hCG) $(2,3)$. Androgens are responsible, during the first trimester, for the differentiation of the Wolffian duct into the epididymis, seminal vesicle, and vas deferens, as well as for the masculinisation of external genitalia. During the third quarter, hCG levels decline, and LH is the main responsible for testosterone and INSL3 secretion. INSL3 and testosterone are involved in testicular descent while testosterone is also responsible for penile growth.

At birth, gonadotropin, testosterone and $\mathrm{AMH}$ levels are transiently low (4). They subsequently increase and remain high during the first 3-6 months of life (5). FSH stimulates Sertoli cell proliferation and AMH secretion (6). Thereafter, gonadotropins decrease again, resulting in a fall of testicular testosterone secretion to very low or undetectable levels during infancy and childhood (Figure 1). Therefore, during childhood, a physiologic state of hypogonadotrophic hypoandrogenism exists, compared with the fetal, neonatal and adult periods. However, Sertoli cells are intensely active: they proliferate resulting in an increase in testis size from approximately $0.5 \mathrm{~cm}^{3}$, in the first year of life, to $1.5 \mathrm{~cm}^{3}$ at 10 years of age (Figure 2$)(7,8)$. AMH, a conspicuous marker of both basal and FSH-stimulated Sertoli cell function, remains high during infancy and childhood (Figure 1).

At the onset of puberty, the reactivation of the hypothalamic-gonadotrophin axis induces the functional activity of Leydig cells again. Intratesticular androgen concentration increases before serum testosterone (9),

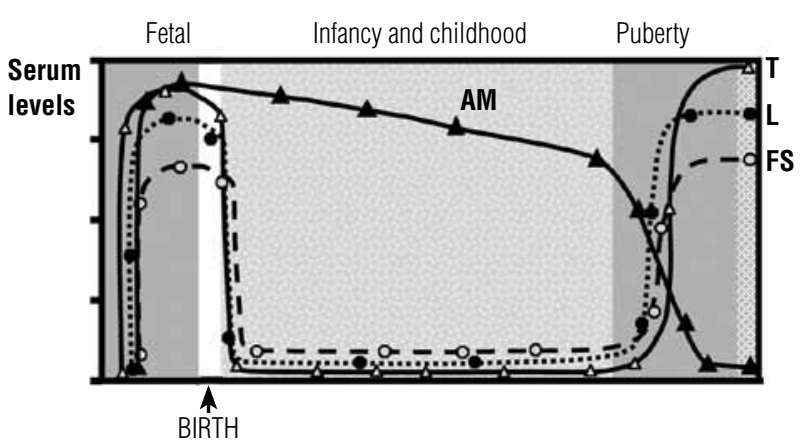

Figure 1. Schematic ontogeny of circulating levels of gonadotropins, testosterone (T) and anti-Müllerian hormone (AMH) in the male. Reprinted with permission from: Grinspon R. P. and Rey R. A. Anti-Müllerian hormone and Sertoli cell function in paediatric male hypogonadism. Horm Res Paediatr. 2010;73:81-92. Copyright S. Karger A. G., Basel, 2010.

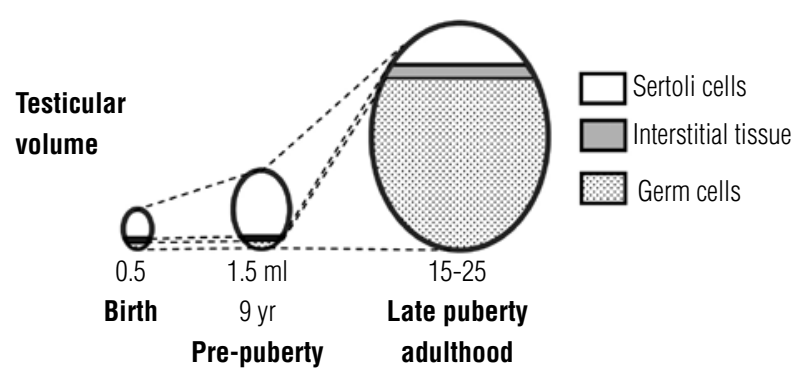

Figure 2. Schematic ontogeny of the evolution of testicular volume from birth to adulthood. Seminiferous tubules (Sertoli + germ cells) are always the major component of the testis. From birth and during the whole prepubertal period (i.e. until ages 9-14 yr, Tanner stage 1), seminiferous tubule volume depends mainly on Sertoli cells, whereas the significant increase in testicular volume during pubertal development (i.e. between Tanner stages 1 and 5 ) is mainly due to germ cell proliferation. Reprinted with permission from: Rey R. Regulation of spermatogenesis. Endocrine Development. 2003;5:38-55. Söder 0 (ed.): The Developing Testis. Physiology and Pathophysiology. Copyright S. Karger A. G., Basel, 2003. 
and provokes Sertoli cell maturation, characterized by arrested proliferation and downregulation of $\mathrm{AMH}$ (Figure 1) (10). Pubertal spermatogenesis is triggered as a result of the production of spermatozoa. Clinically, the onset of puberty is defined by testicular volume $\geq$ $4 \mathrm{~mL}$. The subsequent increase in gonadal size to a final volume of $15-25 \mathrm{~mL}$ is dependent on germ cell proliferation (Figure 2), which depends on intratesticular androgen levels, and normal androgen receptor function in Sertoli cells.

\section{AMH AND SERTOLI CELL PHYSIOLOGY}

$\mathrm{AMH}$ is a distinctive marker of immature Sertoli cells. Serum AMH is transiently low in the first weeks after birth, then increases and peaks at the age of 2-3 years, and remains high until the onset of puberty. Then, AMH decreases, mainly between pubertal Tanner stages 2 and 3 , to reach low adult levels (Table 1 ) $(11,12)$.

The onset of AMH expression in fetal life and the maintenance of its basal levels are gonadotropin-independent (13). However, serum AMH is low in patients with congenital hypogonadotropic hypogonadism, and increases in response to exogenous FSH administration (14-16), indicating that serum AMH is a useful marker of FSH action on the prepubertal testis. Low serum AMH correlates with small testes (6).

Androgens are potent inhibitors of AMH production in Sertoli cells during normal pubertal development. The negative correlation between testosterone and $\mathrm{AMH}$ is observed also in central early puberty and

Table 1. Serum AMH in normal males, using the AMH/MIS ELISA from Beckman-Coulter-Immunotech. Data from reference (11)

\begin{tabular}{|c|c|c|}
\hline \multirow[t]{2}{*}{ Age group } & \multicolumn{2}{|c|}{$\begin{array}{c}\text { Serum AMH } \\
\text { Median }\left(3^{\left.\text {rd }-97^{\text {th }} \text { percentiles }\right)}\right.\end{array}$} \\
\hline & pmol/L & $\mu g / L$ \\
\hline $0-14$ days & $584(253-1038)$ & $82(35-145)$ \\
\hline 15 days -6 months & $697(421-1470)$ & 98 (59-206) \\
\hline 6 months - 2 years & $1132(684-2329)$ & $159(96-326)$ \\
\hline $2-9$ years & $684(236-1831)$ & $96(33-256)$ \\
\hline \multicolumn{3}{|l|}{$9-18$ years } \\
\hline G1 & 713 (257-1371) & $100(36-192)$ \\
\hline G2 & 295 (69-1017) & $41(10-142)$ \\
\hline G3 & $71(30-423)$ & $10(4-59)$ \\
\hline G4 & $65(33-164)$ & $9(5-23)$ \\
\hline G5 & $82(38-195)$ & $11(5-27)$ \\
\hline
\end{tabular}

in gonadotropin-independent early puberty (testotoxicosis), suggesting that androgens are responsible for AMH downregulation, independent of age and gonadotropin levels (17). Furthermore, in patients with defective androgen production or sensitivity, AMH levels are abnormally elevated $(18,19)$. The inhibitory effect of androgens prevails over the positive effect of FSH on AMH secretion in the pubertal testis (Figure 3). In the fetal and neonatal testis, high androgen levels are unable to downregulate AMH production owing to physiological androgen insensitivity of Sertoli cells in these periods. In fact, Sertoli cell nuclei lack androgen receptor expression before the age of 6 months (Figure 3) (16,20-22).

\section{DEFINITIONS AND CLASSIFICATION OF MALE HYPOGONADISM}

In the adult male, hypogonadism refers to testicular failure associated with androgen deficiency and/or disorders in sperm production. This classical definition does not take into account the potential deficiencies in Sertoli cells. In the prepubertal male, Sertoli cells are the most active testicular cell population, while testosterone and sperm production are physiologically inexistent. Therefore, male hypogonadism in the boy can only be discovered if Sertoli cell function is assessed.

\section{Classification of hypogonadism (Table 2)}

\section{Hypothalamic-pituitary (central), testicular (primary), or combined hypogonadism}

Central hypogonadism is characterised by gonadal failure owing to a central disorder affecting the hypothalamic GnRH pulse generator, or pituitary gonadotroph $\mathrm{LH} / \mathrm{FSH}$ secretion. In primary hypogonadism, primary testicular failure exists. Finally, certain disorders may concomitantly impair the hypothalamic-pituitary axis and the testis, and provoke combined hypogonadism.

\section{Whole or dissociated testicular faillure}

Primary, central or combined hypogonadism may reflect the concomitant impairment of all testicular cell populations, i.e., "whole testicular failure or hypogonadism". Conversely, when only one testicular compartment (seminiferous tubules or interstitial tissue) is primarily affected, there is "dissociated testicular failure or hypogonadism". 


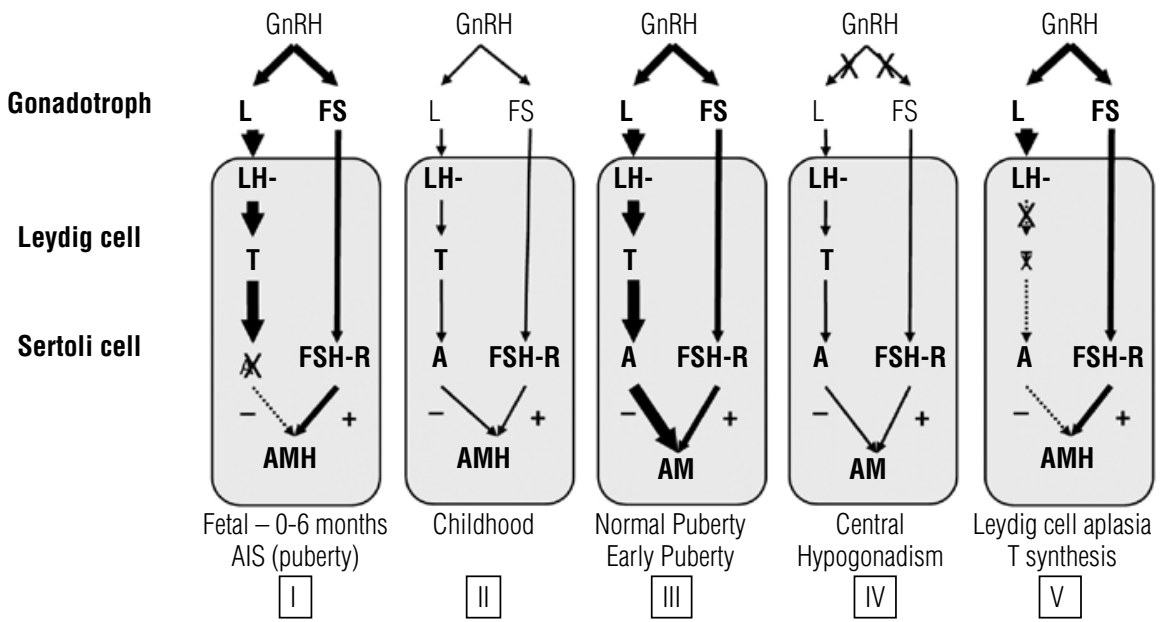

Figure 3. Regulation of testicular AMH secretion by gonadotropins and androgens. In general, the hypothalamus regulates LH and FSH secretion of the gonadotroph by means of gonadotropin-releasing hormone (GnRH). LH acts on the LH receptor (LH-R) present in Leydig cells, inducing testosterone (T) secretion. FSH acts on the FSH receptor (FSH-R) present in Sertoli cells. The hypothalamic-pituitary-gonadal axis is active in the fetus and early infancy, is quiescent during childhood, and is reactivated in puberty. FSH is a moderate inducer of AMH secretion, whereas T, acting by means of the androgen receptor (AR), is a potent inhibitor of AMH production. In the normal fetus and infant, as well as in patients with androgen insensitivity syndrome (AIS), the lack of AR expression results in high AMH production by Sertoli cells (I). During childhood, there is a physiologic hypogonadotrophic state resulting in very low T; AMH levels remain high, but somewhat lower, probably due to the lack of FSH stimulus (II). In normal or early puberty, T prevails over FSH, resulting in AMH inhibition (III). In congenital central hypogonadism, AMH is lower than in the normal boy because of the longstanding lack of FSH from fetal life; however, at pubertal age, the inhibitory effect of T is also absent, and AMH remains higher than in normal puberty (IV). In Leydig cell-specific primary hypogonadism (Leydig cell aplasia or hypoplasia due to LH-R defects, or in defects of steroidogenesis), the inhibitory effect of androgens is absent, and AMH levels are high. The orange area represents the testis. Thickness of lines is correlated with hormone effect on its target. Reprinted with permission from: Grinspon R. P. and Rey R. A. AntiMüllerian hormone and Sertoli cell function in paediatric male hypogonadism. Horm Res Paediatr. 2010;73:81-92. Copyright S. Karger A. G., Basel, 2010.

Table 2. Classification of hypogonadism

\begin{tabular}{|c|c|c|}
\hline & \multicolumn{2}{|c|}{ Central hypogonadism } \\
\hline & Whole gonadal dysfunction & Cell-specific gonadal dysfunction \\
\hline Fetal-onset ( $2^{\text {nd }}-3^{\text {rd }}$ quarters $)$ & $\begin{array}{l}\text { Isolated hypogonadotropic hypogonadism (IHH) } \\
\text { Multiple pituitary-hormone-deficiency }\end{array}$ & $\begin{array}{l}\text { Leydig cells: LH } \beta \text {-subunit gene mutation } \\
\text { Sertoli cells: FSH } \beta \text {-subunit gene mutation }\end{array}$ \\
\hline Childhood-onset & $\begin{array}{l}\text { Endocrine disorders: hypothyroidism, hyperprolactinemia } \\
\text { Central Nervous System tumours, Langerhan's hystiocytosis }\end{array}$ & None \\
\hline \multirow[t]{3}{*}{ Peri-pubertal } & $\begin{array}{l}\text { Functional central hypogonadism: anorexia nervosa } \\
\text { Endocrine disorders: hypothyroidism, hyperprolactinemia } \\
\text { Central Nervous System tumours, Langerhan's hystiocytosis }\end{array}$ & None \\
\hline & \multicolumn{2}{|c|}{ Primary hypogonadism } \\
\hline & Whole gonadal dysfunction & Cell-specific gonadal dysfunction \\
\hline Fetal-onset (1st quarter) & Gonadal dysgenesis & $\begin{array}{l}\text { Leydig cell aplasia/hypoplasia } \\
\text { Steroidogenic protein defects } \\
\text { Sertoli cell: PMDS due to AMH mutation }\end{array}$ \\
\hline Fetal-onset ( $2^{\text {nd }}-3^{\text {rd }}$ quarters $)$ & $\begin{array}{l}\text { Endocrine disruptors } \\
\text { Testicular regression syndrome } \\
\text { Testicular torsion }\end{array}$ & Sertoli cell: FSH-R mutation \\
\hline Childhood-onset & $\begin{array}{c}\text { Cryptorchidism } \\
\text { Testicular torsion } \\
\text { Orchitis } \\
\text { Chemotherapy/Radiotherapy } \\
\text { Trisomy } 21\end{array}$ & None \\
\hline \multirow[t]{3}{*}{ Peri-pubertal } & $\begin{array}{c}\text { Cryptorchidism } \\
\text { Testicular torsion } \\
\text { Orchitis } \\
\text { Chemotherapy/Radiotherapy } \\
\text { Klinefelter syndrome }\end{array}$ & Germ cells: XX male \\
\hline & \multicolumn{2}{|c|}{ Combined hypogonadism } \\
\hline & Whole gonadal dysfunction & Cell-specific gonadal dysfunction \\
\hline Fetal-onset (1 ${ }^{\text {st }}$ quarter) & DAX1 gene mutations & None \\
\hline Fetal-onset ( $2^{\text {nd }}-3^{\text {rd }}$ quarter $)$ & Prader-Willi syndrome & None \\
\hline Childhood-onset & Total body irradiation & None \\
\hline Peri-pubertal & Total body irradiation & None \\
\hline
\end{tabular}




\section{Fetal-, childhood-, pubertal-onset hypogonadism}

Male hypogonadism yields different clinical consequences depending on the period of life in which it is established. Fetal-onset hypogonadism, established early in the $\mathrm{l}^{\text {st }}$ quarter, results in disorders of sex development, with ambiguous or female genitalia due to insufficient testis hormone levels during the critical window of male sex differentiation. Gonadal dysgenesis is an example of whole gonadal dysfunction, whereas Leydig cell aplasia/hypoplasia and steroidogenic defects are dissociated forms of hypogonadism. Central hypogonadism cannot result in genital ambiguity, since Leydig cell function in the $\mathrm{l}^{\text {st }}$ quarter of fetal life is dependent on placental hCG. Fetal hypogonadism (primary, central or combined) of the $2^{\text {nd }}$ half of gestation typically results in micropenis and cryptorchidism. When established during infancy or childhood, hypogonadism may remain undiagnosed until the age of puberty - unless Sertoli cell function is assessed. At pubertal age, hypogonadism can provoke lack or arrest of pubertal development.

\section{PEDIATRIC MALE HYPOGONADISM: USEFULNESS OF AMH LEVELS}

The evaluation of basal testicular function in infancy and childhood relies mainly on the assessment of Sertoli cell markers, since gonadotropin and testosterone levels normally decrease to very low values until the onset of puberty (23-26). Serum AMH reliably reflects the presence and function of testes in prepubertal boys, without the need for any stimulation test $(24,27,28)$. To evaluate gonadotrophs or Leydig cell function, dynamic tests are necessary.

\section{Central hypogonadism with "whole testicular dysfunction"}

\section{Isolated hypogonadotropic hypogonadism and multiple pituitary hormone deficiency}

Serum AMH levels are low in infants with congenital central hypogonadism. Early treatment with FSH results in testicular growth - owing to Sertoli cell proliferation - and serum AMH elevation (14). In untreated patients of pubertal age, serum AMH is elevated for age (because serum testosterone remains at prepubertal levels and does not downregulate $\mathrm{AMH}$ ), but lower than expected for patient's Tanner stage and serum testosterone $(15,29)$, which reflects the lack of FSH stimulus (Figure 3). FSH treatment provokes an increase in serum AMH. Further treatment with hCG results in an elevation of intratesticular androgen levels, which inhibit AMH (Figure 4). Conversely, downregulation of $\mathrm{AMH}$ is less significant when patients receive exogenous testosterone, probably due to the lower intratesticular androgen levels obtained with this treatment (15). AMH and inhibin $\mathrm{B}$ are normal in boys with constitutional delay of puberty, reflecting the eugonadal state in these patients $(30,31)$.

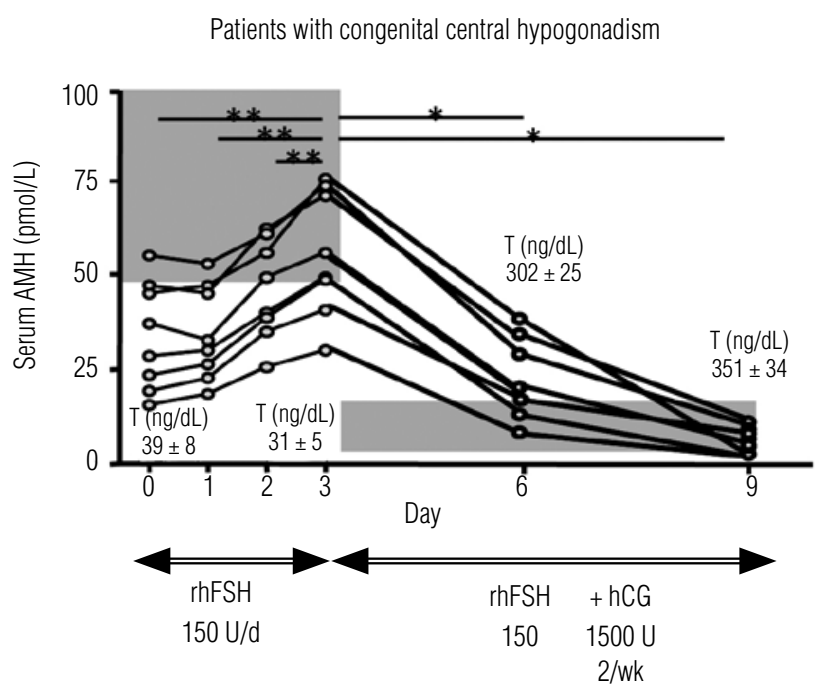

Figure 4. Effect of recombinant human FSH (rhFSH) and hCG treatment on testicular anti-Müllerian hormone (AMH) production by the testis in patients with previously untreated central hypogonadism. Initial treatment with rhFSH during 30 days resulted in an elevation of serum AMH in all 8 patients, while testosterone (T) remained at prepubertal levels. Shaded area represents normal AMH for Tanner I stage, according to T levels observed in these patients. Subsequent addition of hCG treatment resulted in elevation of $\mathrm{T}$, which provoked a decline in serum $\mathrm{AMH}$. Shaded area represents $A M H$ values for Tanner IV-V stages, according to $T$ levels observed in treated patients. Reprinted with permission from: Grinspon R. P. and Rey R. A. Anti-Müllerian hormone and Sertoli cell function in paediatric male hypogonadism. Horm Res Paediatr. 2010;73:81-92. Copyright S. Karger A. G., Basel, 2010.

\section{Central hypogonadism with "dissociated testicular dysfunction"}

\section{Central hypogonadism with Leydig cell-specific dysfunction}

Isolated LH deficiency, due to mutations of the LH $\beta$ subunit gene, results in failure of Leydig cell differentiation and testosterone secretion in late fetal life and pubertal age (32). In mice, FSH levels are usually elevated and Sertoli cells remain immature, producing high AMH levels (33). 
Primary hypogonadism with "whole testicular dysfunction"

\section{Gonadal dysgenesis, vanishing testes and anorchia}

Gonadal dysgenesis established in the first quarter of fetal life results in female or ambiguous genitalia, reflecting the degree of testicular hormone deficiency. Vanishing or regression of testicular tissue occurring in the second half of fetal life does not preclude virilisation, but micropenis and hypoplastic scrotum occur. In all cases, serum AMH is low or undetectable, according to the amount of testicular tissue remaining $(19,27,28)$.

In boys with isolated hypospadias but normal penis size and scrotum and descended testes, AMH and testosterone are normal, indicating that there is no testicular dysfunction (34).

Klinefelter syndrome is a sex-chromosome aneuploidy characterised by late-onset testicular dysgenesis. AMH levels are normal until pubertal Tanner stage 3, in correlation with normal inhibin B and FSH. Thereafter, Sertoli cell function deteriorates progressively, resulting in extremely low or undetectable AMH, together with undetectable inhibin B, very high FSH levels and small testis volume (35). Another aneuploidy with primary hypogonadism is trisomy $2 \mathrm{l}$; however, both the tubular and interstitial compartments are affected in a high proportion of these patients from early infancy. Serum $\mathrm{AMH}$ is low and testosterone reaches low/normal levels but with high LH (11).

\section{Cryptorchidism}

Rather than a pathology, cryptorchidism is a clinical a sign with many possible etiologies. It may reflect a primary hypogonadal disorder with "whole testicular dysfunction", result from hypogonadotropic hypogonadism, or from rare mutations of INSL3 or its receptor (3), or even from anatomical defects of the inguinal region or abdominal wall (i.e., not associated with hypogonadism). According to its etiology, cryptorchidism may be associated with normal or impaired Sertoli cell function. In boys with bilateral cryptorchidism, AMH is low in approximately $75 \%$ of those with nonpalpable gonads and $35 \%$ of those with inguinal gonads, indicating Sertoli cell dysfunction (36). AMH is expected to be normal in infants with abdominal wall or inguinal region defects, or with impaired INSL3 signalling. As previously discussed, AMH levels are low in patients with hypogonadotropic hypogonadism $(14,15,29)$.

\section{Chemotherapy/Radiotherapy}

Chemotherapy and radiotherapy affect primarily germ cells (37). No studies have reported AMH values in these cases.

\section{Primary hypogonadism with "dissociated testicular dysfunction"}

\section{Primary hypogonadism with Sertoli cell-specific dysfunction}

FSH receptor mutations result in reduced Sertoli cell number and function, leading to small testis size, low inhibin B and moderately elevated FSH (38). Low AMH could be expected, but no reports exist. Because basal AMH secretion in early fetal life is FSH-independent, Müllerian ducts normally regress in these patients.

$\mathrm{AMH}$ gene mutations are responsible for the AMHnegative form of the Persistent Müllerian Duct Syndrome (PMDS), characterized by undetectable serum $\mathrm{AMH}$. A distinction should be made from the AMHpositive form of PMDS due to AMH receptor mutations, where serum AMH is normal, indicating a eugonadal state [reviewed in ref. (39)].

\section{Primary hypogonadism with Leydig cell-specific dysfunction}

Inactivating mutations of the LH/CG receptor or steroidogenic enzymes in 46,XY individuals result in isolated hypoandrogenism leading to the development of female or ambiguous external genitalia. It is possible to distinguish these types of disorders of sex differentiation with those resulting from testicular dysgenesis (i.e. whole gonadal dysfunction) because serum AMH is normal/high owing to the lack of androgen inhibitory effect (Figure 3) (19).

\section{Primary hypogonadism with germ cell-specific dysfunction}

In XX males, $\mathrm{AMH}$ and testosterone are normal, indicating that the somatic cells of the gonads are not primarily affected (19). However, germ cells fail to progress to gametogenesis, and enter apoptosis in puberty.

AMH levels have not been evaluated in other disorders where germ cells are the primarily affected population, like DAZ (Deleted in Azoospermia) microdeletions of the $\mathrm{Y}$ chromosome.

Combined hypogonadism (central and primary) with "whole testicular dysfunction". 
DAXl is expressed at several levels of the hypothalamic-pituitary-gonadal and adrenal axes (40). DAXI gene mutations cause an $\mathrm{X}$-linked disorder characterized by congenital adrenal hypoplasia, and hypothalamic-pituitary hypogonadism combined with testicular origin. There is a primary testicular defect (41) associated with a lack of gonadotropin elevation, due to impaired functional capacity of the pituitary. Both Serum $\mathrm{AMH}$ and inhibin $\mathrm{B}$ are low since early pubertal stages, indicating the existence of a primary failure of testicular function (42).

Prader-Willi syndrome is another form of combined central and peripheral hypogonadism. Boys and adolescents present normal/low AMH, low inhibin B, normal/low testosterone and normal/high FSH and $\mathrm{LH}$ (43-45).

\section{CONCLUDING REMARKS}

The diagnosis of hypogonadism may be missed in infancy and childhood if attention is driven only to gonadotropins and testosterone. Sertoli cells are the main active population during prepubertal ages. Small testes are indicative of reduced number of Sertoli cells, either primary or secondary to FSH deficiency. Sertoli cell markers, like serum $\mathrm{AMH}$ and inhibin $\mathrm{B}$, are most helpful in the evaluation of gonadal function, without the need for stimulation tests, and guide the etiological diagnosis of male hypogonadism in pediatric patients. Serum AMH is an excellent marker of FSH and androgen action in the testis.

Disclosure: Rodolfo A. Rey has received royalties from Beckman-Coulter France as the inventor of AMH/MIS ELISA ${ }^{\circledR}$. Romina P. Grinspon has no conflicts of interest to disclose.

\section{REFERENCES}

1. Petersen C, Söder O. The Sertoli cell: a hormonal target and 'super' nurse for germ cells that determines testicular size. Horm Res. 2006;66:153-61.

2. Svechnikov K, Söder O. Ontogeny of gonadal sex steroids. Best Pract Res Clin Endocrinol Metab. 2008;22:95-106.

3. Ivell $\mathrm{R}$, Hartung $\mathrm{S}$. The molecular basis of cryptorchidism. Mol Hum Reprod. 2003;9:175-81.

4. Bergadá I, Milani C, Bedecarrás P, Andreone L, Ropelato MG, Gottlieb $S$, et al. Time course of the serum gonadotropin surge, inhibins, and anti-Müllerian hormone in normal newborn males during the first month of life. J Clin Endocrinol Metab. 2006;91:4092-8.

5. Forest MG, Sizonenko PC, Cathiard AM, Bertrand J. Hypophyso-gonadal function in humans during the first year of life. 1. Evidence for testicular activity in early infancy. J Clin Invest. 1974;53:819-28.
6. Lukas-Croisier C, Lasala C, Nicaud J, Bedecarrás P, KumarTR, Dutertre $\mathrm{M}$, et al. Follicle-stimulating hormone increases testicular anti-Müllerian hormone (AMH) production through Sertoli cell proliferation and a nonclassical cyclic adenosine 5'-monophosphate-mediated activation of the $\mathrm{AMH}$ gene. Mol Endocrinol. 2003;17:550-61.

7. Müller J, Skakkebæk NE. Quantification of germ cells and seminiferous tubules by stereological examination of testicles from 50 boys who suffered from sudden death. Int J Androl. 1983;6:143-56.

8. Nistal M, Abaurrea MA, Paniagua R. Morphological and histometric study on the human Sertoli cell from birth to the onset of puberty. J Anat. 1982;134(Pt 2):351-63.

9. Pasqualini $T$, Chemes $H$, Rivarola MA. Testicular testosterone levels during puberty in cryptorchidism. Clin Endocrinol. 1981;15:545-54.

10. Rey R, Lukas-Croisier C, Lasala C, Bedecarrás P. AMH/MIS: what we know already about the gene, the protein and its regulation. Mol Cell Endocrinol. 2003;211:21-31.

11. Grinspon RP, Bedecarrás $P$, Ballerini $M G$, Iñíguez $G$, Rocha $A$, Resende EAMR, et al. Early onset of primary hypogonadism revealed by serum anti-Müllerian hormone determination during infancy and childhood in trisomy 21. Int J Androl. 2011;34(5 Pt 2):e487-98.

12. Aksglaede $L$, Sorensen $K$, Boas $M$, Mouritsen $A$, Hagen $C P$, Jensen $R B$, et al. Changes in Anti-Müllerian hormone (AMH) throughout the life span: a population-based study of 1027 healthy males from birth (cord blood) to the age of 69 years. J Clin Endocrinol Metab. 2010;95:5357-64.

13. Lasala C, Carré-Eusèbe D, Picard JY, Rey R. Subcellular and molecular mechanisms regulating anti-Mullerian hormone gene expression in mammalian and nonmammalian species. DNA Cell Biol. 2004;23:572-85.

14. Bougnères $P$, François $M$, Pantalone $L$, Rodrigue $D$, Bouvattier $C$, Demesteere $E$, et al. Effects of an early postnatal treatment of hypogonadotropic hypogonadism with a continuous subcutaneous infusion of recombinant follicle-stimulating hormone and luteinizing hormone. J Clin Endocrinol Metab. 2008;93:2202-5.

15. Young J, Chanson P, Salenave S, Noël M, Brailly S, O'Flaherty M, et al. Testicular anti-Müllerian hormone secretion is stimulated by recombinant human $\mathrm{FSH}$ in patients with congenital hypogonadotropic hypogonadism. J Clin Endocrinol Metab. 2005;90:724-8.

16. Al-Attar L, Noël K, Dutertre M, Belville C, Forest MG, Burgoyne PS, et al. Hormonal and cellular regulation of Sertoli cell anti-Müllerian hormone production in the postnatal mouse. J Clin Invest. 1997;100:1335-43.

17. Rey R, Lordereau-Richard I, Carel JC, Barbet P, Cate RL, Roger M, et al. Anti-Müllerian hormone and testosterone serum levels are inversely related during normal and precocious pubertal development. J Clin Endocrinol Metab. 1993;77:1220-6.

18. Rey R, Mebarki F, Forest MG, Mowszowicz I, Cate RL, Morel Y, et al. Anti-Müllerian hormone in children with androgen insensitivity. J Clin Endocrinol Metab. 1994;79:960-4.

19. Rey RA, Belville C, Nihoul-Fékété C, Michel-Calemard L, Forest MG, Lahlou N, et al. Evaluation of gonadal function in 107 intersex patients by means of serum anti-Müllerian hormone measurement. J Clin Endocrinol Metab. 1999;84:627-31.

20. Chemes HE, Rey RA, Nistal M, Regadera J, Musse M, Gonzalez-Peramato $P$, et al. Physiologic androgen insensitivity of the fetal, neonatal, and early infantile testis is explained by the ontogeny of the androgen receptor expression in Sertoli cells. J Clin Endocrinol Metab. 2008;93:4408-12.

21. Berensztein EB, Baquedano MS, Gonzalez CR, Saraco NI, Rodriguez J, Ponzio R, et al. Expression of aromatase, estrogen receptor alpha and beta, androgen receptor, and cytochrome P-450scc in the human early prepubertal testis. Pediatr Res. 2006;60:740-4. 
22. Boukari K, Meduri G, Brailly-Tabard S, Guibourdenche J, Ciampi ML, Massin N, et al. Lack of androgen receptor expression in Sertoli cells accounts for the absence of anti-Müllerian hormone repression during early human testis development. J Clin Endocrinol Metab. 2009;94:1818-25.

23. Andersson AM. Inhibin B in the assessment of seminiferous tubular function. Baillieres Best Pract Res Clin Endocrinol Metab. 2000;14:389-97.

24. Rey R. Assessment of seminiferous tubule function (anti-Müllerian hormone). Baillieres Best Pract Res Clin Endocrinol Metab. 2000;14:399-408.

25. Bergadá I, Bergadá C, Campo SM. Role of inhibins in childhood and puberty. J Pediatr Endocrinol Metab. 2001;14:343-53.

26. Lee MM, Misra M, Donahoe PK, MacLaughlin DT. MIS/AMH in the assessment of cryptorchidism and intersex conditions. Mol Cell Endocrinol. 2003;211:91-8.

27. Lee MM, Donahoe PK, Silverman BL, Hasegawa T, Hasegawa $Y$, Gustafson ML, et al. Measurements of serum Müllerian inhibiting substance in the evaluation of children with nonpalpable gonads. N Engl J Med. 1997;336:1480-6.

28. Josso N. Paediatric applications of anti-Müllerian hormone research. 1992 Andrea Prader Lecture. Horm Res. 1995;43:243-8.

29. Young J, Rey R, Couzinet B, Chanson P, Josso N, Schaison G.Anti-Müllerian hormone in patients with hypogonadotropic hypogonadism. J Clin Endocrinol Metab. 1999;84:2696-9.

30. Adan L, Lechevalier P, Couto-Silva AC, Boissan M, Trivin C, Brailly-Tabard S, et al. Plasma inhibin B and anti-Müllerian hormone concentrations in boys: Discriminating between congenital hypogonadotropic hypogonadism and constitutional pubertal delay. Med Sci Monit. 2010;16:CR511-7.

31. Coutant R, Biette-Demeneix E, Bouvattier C, Bouhours-Nouet N, Gatelais F, Dufresne S, et al. Baseline inhibin B and anti-Müllerian hormone measurements for diagnosis of hypogonadotropic hypogonadism $(\mathrm{HH})$ in boys with delayed puberty. J Clin Endocrinol Metab. 2010;95:5225-32.

32. Weiss J, Axelrod L, Whitcomb RW, Harris PE, Crowley WF, Jameson JL. Hypogonadism caused by a single amino acid substitution in the beta subunit of luteinizing hormone [see comments]. N Engl J Med. 1992;326:179-83.

33. Ma X, Dong Y, Matzuk MM, Kumar TR. Targeted disruption of luteinizing hormone beta-subunit leads to hypogonadism, defects in gonadal steroidogenesis, and infertility. PNAS U S A. 2004;101:17294-9.
34. Rey RA, Codner E, Iñíguez G, Bedecarrás P, Trigo R, Okuma C, et al. Low risk of impaired testicular Sertoli and Leydig cell functions in boys with isolated hypospadias. J Clin Endocrinol Metab. 2005;90:6035-40.

35. Bastida MG, Rey RA, Bergadá I, Bedecarrás $P$, Andreone L, del Rey $\mathrm{G}$, et al. Establishment of testicular endocrine function impairment during childhood and puberty in boys with Klinefelter syndrome. Clin Endocrinol. 2007;67:863-70.

36. Misra M, MacLaughlin DT, Donahoe PK, Lee MM. Measurement of Müllerian inhibiting substance facilitates management of boys with microphallus and cryptorchidism. J Clin Endocrinol Metab. 2002;87:3598-602.

37. Shalet $\mathrm{SM}$, Tsatsoulis $A$, Whitehead $E$, Read G. Vulnerability of the human Leydig cell to radiation damage is dependent upon age. J Endocrinol. 1989;120:161-5.

38. Tapanainen JS, Aittomaki K, Min J, Vaskivuo T, Huhtaniemi IT. Men homozygous for an inactivating mutation of the follicle-stimulating hormone (FSH) receptor gene present variable suppression of spermatogenesis and fertility. Nat Genet. 1997;15:205-6.

39. Josso N, Belville C, di Clemente N, Picard JY. AMH and AMH receptor defects in persistent Müllerian duct syndrome. Hum Reprod Update. 2005;11:351-6.

40. Yu RN, Achermann JC, Ito M, Jameson JL. The role of DAX-1 in reproduction. Trends Endocrinol Metab. 1998;9:169-75.

41. Meeks JJ, Crawford SE, Russell TA, Morohashi K, Weiss J, Jameson JL. Dax1 regulates testis cord organization during gonadal differentiation. Development. 2003;130:1029-36.

42. Bergadá I, Andreone L, Bedecarrás $P$, Ropelato MG, Copelli $S$, Laissue $P$, et al. Seminiferous tubule function in delayed-onset $X$-linked adrenal hypoplasia congenita associated with incomplete hypogonadotrophic hypogonadism. Clin Endocrinol. 2008;68:240-6.

43. Eiholzer U, l'Allemand D, Rousson V, Schlumpf M, GasserT, Girard $J$, et al. Hypothalamic and gonadal components of hypogonadism in boys with Prader-Labhart- Willi Syndrome. J Clin Endocrinol Metab. 2006;91:892-8.

44. Fillion M, Deal CL, Van Vliet G. Normal minipuberty of infancy in boys with Prader-Willi syndrome. J Pediatr. 2006;149:874-6.

45. Hirsch HJ, Eldar-Geva T, Benarroch F, Rubinstein O, Gross-Tsur V. Primary testicular dysfunction is a major contributor to abnormal pubertal development in males with Prader-Willi syndrome. J Clin Endocrinol Metab. 2009;94:2262-8. 